\title{
Colonization of Greek olive cultivars' root system by arbuscular mycorrhiza fungus: root morphology, growth, and mineral nutrition of olive plants
}

\author{
Theocharis Chatzistathis ${ }^{1 *}$, Michail Orfanoudakis ${ }^{2}$, Dimitrios Alifragis ${ }^{3}$, loannis Therios ${ }^{1}$
}

\author{
${ }^{1}$ Aristotle University/School of Agriculture - Lab. of \\ Pomology, 54124 - Thessaloniki - Greece. \\ ${ }^{2}$ Democritus University of Thrace - Lab. of Forest Soil - \\ Dept. of Forestry and Management of the Environment and \\ Natural Resources, Pantazidou 193 - 68200 - Orestiada \\ - Greece. \\ ${ }^{3}$ Aristotle University/School of Forestry and Natural \\ Environment - Lab. of Forest Soils, 54124 - Thessaloniki - \\ Greece. \\ *Corresponding author <ChChatzi@in.gr>
}

Edited by: Cláudio Marcelo Gonçalves de Oliveira

Received October 03, 2012

Accepted January 08, 2013

\begin{abstract}
Rooted leafy cuttings of three Greek olive (Olea europaea L.) cultivars (Koroneiki, Kothreiki and Chondrolia Chalkidikis) were grown for six months in three soil types, in an experimental greenhouse, in order to investigate: i) if their root system was colonized by arbuscular mycorrhiza fungus (AMF) genus and, ii) if genotypic differences concerning growth and mineral nutrition of olive plants existed. Gigaspora sp. colonized the root system of the three cultivars studied, while Glomus sp. colonized only the root system of 'Koroneiki'. Furthermore, in most cases root colonization by AMF differed among cultivars and soil types. The maximum root colonization, in all soils, was found in 'Chondrolia Chalkidikis'. In the three soils studied, the ratio shoot dry weight (SDW)/ root dry weight (RDW) was higher in 'Chondrolia Chalkidikis' than in the other two cultivars. Furthermore, root system morphology of the three olive cultivars was completely different, irrespectively of soil type. Leaf Mn, Fe, Zn, Ca, Mg, K and P concentrations, as well as total per plant nutrient content and nutrient use efficiency, differed among cultivars under the same soil conditions. These differences concerning root morphology, SDW/RDW, as well as nutrient uptake and use efficiency, could be possibly ascribed to the differential AMF colonization by Glomus sp. and Gigaspora sp.

Keywords: 'Chondrolia Chalkidikis', 'Koroneiki', ‘Kothreiki', root colonization, soil type
\end{abstract}

\section{Introduction}

Mycorrhizal associations are generally characterized as affording mutual benefits to the symbiotic fungus and the host plant (Ducic et al., 2008). Arbuscular mycorrhiza fungus (AMF) colonization affects root system morphology and nutrient uptake (Citernesi et al., 1998; Malusa et al., 2007). The nutrients whose uptake is mostly influenced by AMF are $\mathrm{P}, \mathrm{Fe} \mathrm{Mn}$ and $\mathrm{Zn}$ (Pasqualini et al., 2007; Ducic et al., 2008; Dag et al., 2009; Sudova, 2009; Cavagnaro et al., 2010; Orlowska et al., 2011) and sometimes K (Marulanda et al., 2007; Dag et al., 2009). Mycorrhizal plants may also be used as phytoremediators due to the enhanced capacity of host plants to absorb heavy metals (Orlowska et al., 2011).

Apart from the influence of AMF on nutrient uptake, other positive aspects of mycorrhization include raise of plant growth (Pasqualini et al., 2007; Dag et al., 2009; Sheng et al., 2009; Shokri and Maadi, 2009), increase of the rate of photosynthesis and transpiration, greater stomatal conductance (Caravaca et al., 2003; Wu and Zou, 2010), enhancement of nursery and post-transplant field response and decrease of transplanting stress (Carretero et al., 2009; Dag et al., 2009), increase of plant tolerance to drought (Marulanda et al., 2007), salt stress (Sheng et al., 2009) and serpentine edaphic stress (Doubkova et al., 2012), as well as protection from nematodes attack (Castillo et al., 2006), improvement of water use efficiency (Bolandnazar et al., 2007) and amelioration of fruit quality (Nzanza et al., 2012).

Various genotypes of the same plant species have the ability to accumulate different amounts of nutri- ents. Particularly, many olive (Olea europaea L.) cultivars are very often grown under the same soil conditions in Greece and have the ability to absorb and accumulate different amounts of nutrients (Chatzistathis et al., 2009). However, it has not been investigated until now if the root system of different olive cultivars, having the ability to accumulate different amounts of nutrients and to grow differentially under the same soil conditions, is colonized by different AMF genera, or/and if the abundance of AMF differs significantly among cultivars, since mycorrhiza affects root system morphology (Citernesi et al., 1998; Malusa et al., 2007).

This study aimed to investigate if differential symbiosis between AMF and olive plants' root system was developed in three Greek olive cultivars, grown under three soil types.

\section{Materials and Methods}

\section{Plant material and soil sampling}

Two-month-old rooted olive cuttings (O. europaea, cvs. Koroneiki, Kothreiki and Chondrolia Chalkidikis), about $15-\mathrm{cm}$ high, were grown for six months (from 04 Jan. to $02 \mathrm{Jul}$.) in black plastic bags, containing $3 \mathrm{~kg}$ of soil, inside an experimental greenhouse. The plants of each cultivar were randomized, based on their initial height and fresh weight, in three similar groups (corresponding to the three soils used) and five replicates (plants) per soil type were included. The total number of plants was 45 (three soils $\times$ three cultivars $\times$ five replicates per soil type and olive cultivar). Three soils, derived from different parent material (Marl, Gneiss schist and Peridotite) and having different physicochemical 
properties, were included in this study. These soils were collected from areas around the city of Thessaloniki and represent the three basic soil types where olive trees are growing in the region of Thessaloniki $(22.94 \mathrm{~N}$ and 40.64 E), Macedonia, northern Greece. The previous mentioned soils belong to the category of Entisols (Orthents), according to the Soil Taxonomy system (1975). The soil samples were collected from the upper $60 \mathrm{~cm}$ of each soil, where most of the olive root system is distributed. This soil layer included the $A_{p}$ and $A_{c}$ horizons in the Marl soil, $A_{p}$ in the Gneiss schist and A and B horizons in the Peridotite soil. During the whole experimental period, all the plants were irrigated with $200 \mathrm{~mL}$ distilled water (they were irrigated every third day from Jan. to early May and every second day from May until the end of the experiment due to increased transpiration), but they were not fertilized in order to permit the growth of AMF in their root system (Chatzistathis et al., 2010).

\section{Chemical analyses of soil samples}

Soil samples were dried at room temperature, their stones were removed, and afterwards were sieved to pass a 10 mesh screen before analyses. General chemical analyses, as well as extraction of micronutrients, were conducted in each one of the three soils. General chemical analyses of the soils included the $\mathrm{pH}$ measurement, the content of organic matter, the exchangeable cations $\mathrm{Ca}, \mathrm{Mg}$ and $\mathrm{K}$, the particle size analysis and the content of $\mathrm{CaCO}_{3}$. The $\mathrm{pH}$ was determined in soil: distilled water solution mixture 1:1 (Bates, 1964), the organic matter was determined with the $\mathrm{K}_{2} \mathrm{Cr}_{2} \mathrm{O}_{7}$ method (Allison, 1965), the exchangeable cations according to the method of $\mathrm{CH}_{3}$ $\mathrm{COONH}_{4}$ of $\mathrm{pH} 9$ (pH 9 was chosen in order to reduce the $\mathrm{CaCO}_{3}$ solubilization, as $\mathrm{pH}$ values of the three soils were greater than 7) (Bower et al., 1952) and the particle size analysis according to the 'Bouyoucos' method. The 'Bouyoucos' method provides generally reliable results for particle size soil analysis (Klute, 1986). Finally, the $\mathrm{CaCO}_{3}$ content was determined with the calcium meter method, while the extraction of $\mathrm{Mn}, \mathrm{Fe}, \mathrm{Zn}$ in the three soil types was conducted with the DTPA method (Alifragis and Papamichos, 1995).

\section{Determination of AMF genus colonizing the root system of olive plants}

The method followed to determine AMF genus in the root system of each olive plant was suggested by Koske and Gemma (1989). More specifically, root system samples were elaborated with $10 \% \mathrm{KOH}$ (in room temperature) for cellulose destruction. Afterwards, root samples were treated with $1 \% \mathrm{HCl}$ in order to be acidified and to achieve better staining. Finally, they were elaborated with $10 \% \mathrm{H}_{2} \mathrm{O}_{2}$ for bleaching. The staining of samples was done by trypan blue. Afterwards, root samples were ready for examination by the optical microscopy. AMF genus identification was conducted by the isolated rhizospheric AMF spores.

\section{Plant growth}

At the end of the experiment, main shoot's length, root (fresh and dry) and total plant weight (fresh and dry), as well as the ratio shoot dry weight (SDW)/root dry weight (RDW) were measured.

\section{Leaf tissue analyses}

Leaf samples from the middle of the shoot (mature leaves obtained their full size) were collected, washed once with tap and twice with distilled water, dried at 75 $\mathrm{C}$ for $24 \mathrm{~h}$ and finally ground to a fine powder to pass a 30 mesh screen. A portion of $0.5 \mathrm{~g}$ of the fine powder of each sample was dry-ashed in a muffle furnace at 515 ${ }^{\circ} \mathrm{C}$ for $5 \mathrm{~h}$. Then, the ash was dissolved in $3 \mathrm{~mL}$ of $6 \mathrm{M}$ hydrochloric acid $(\mathrm{HCl})$ and diluted with double distilled water up to $50 \mathrm{~mL}$. The concentrations of the elements $\mathrm{Ca}, \mathrm{Mg}, \mathrm{K}, \mathrm{Mn}, \mathrm{Fe}$ and $\mathrm{Zn}$ were determined by atomic absorption spectroscopy (Perkin-Elmer 2340, Waltham, MA, USA). The concentrations of microelements were expressed in $\mathrm{mg} \mathrm{kg}^{-1} \mathrm{~d}$.w., while those of macronutrients in $\%$ d.w.

\section{Statistics}

The data were statistically analyzed by the TWOWAY analysis of variance (TWO- WAY ANOVA) (using soil type and olive cultivar as main effects) of the SPSS software package (SPSS 16.0.1. for Windows, Chicago, IL), and, particularly for comparison of means between the three olive cultivars and the three soils, the Tukey's post-hoc parametric test was performed, for $p \leq 0.05$. In each soil type and olive cultivar, five replicates were included (i.e. total number of experimental plants: three cultivars* three soil types* five replicates $=45$ ). For comparison of means, concerning the physicochemical properties between the three soil types, the Duncan's multiple range test $(p \leq 0.05)$ was used.

\section{Results}

\section{Physicochemical properties of the three soils}

The soils originated from Marl and Peridotite were sandy-clay-loam (SCL), while that originated from Gneiss schist was sandy-loam (SL) (Table 1). The $\mathrm{pH}$ value of the Gneiss schist soil was 7.1, while that of the Marl and Peridotite soils was 7.6 and 8.0, respectively. The organic matter content of the Gneiss schist soil was relatively low, while that of the other two soils was above the typical average for Greek soils, ranging between 29 and $44 \mathrm{~g} \mathrm{~kg}^{-1}$ soil (Table 1). Calcium carbonate content was medium (154 g $\mathrm{kg}^{-1}$ soil) in the Peridotite soil and very low in the other two soils. Concerning exchangeable cations, Ca dominated in the Marl and Peridotite soils, while in the Gneiss schist one it was approximately $27 \%$ of that in the other two soils. Potassium concentration was more than five times greater in the Peridotite soil, compared to the other two soils. Magnesium concentrations of the three soils were not statistically different. Extractable-according to the Olsen method-phosphorus concentration was significantly 
greater in the Marl soil, compared to the other ones (Table 1). The cation exchange capacity (CEC) was high and almost equal in the Marl and Peridotite soils (43 and 48 $\%$, respectively) and low in the Gneiss schist soil (17\%) (Alifragis, personal communication). The water-holding capacity values of the three soils were 29, 22 and $30 \%$ for the Marl, Gneiss schist and Peridotite soils, respectively (Alifragis, personal communication). Finally, the greatest concentration of the DTPA extractable Mn was recorded in the Peridotite soil, while in the other two soils it was only about $50 \%$ of that in the Peridotite soil; Fe and $\mathrm{Zn}$ concentrations were not different $(p<0.05)$ among the three soil types (Table 1) (Chatzistathis et al., 2010).

\section{Colonization of olive plants' root system by AMF}

Gigaspora sp. colonized the root system of the three olive cultivars studied, while Glomus sp. colonized only the root system of 'Koroneiki' (Figures 1 and 2); furthermore, differences between cultivars in the same soil type, as well as among soil types for 'Chondrolia Chalkidikis', have been observed concerning the percentage of root system colonization by AMF. This percentage varied between 45 and $73 \%$ among the three olive cultivars and soil types (Table 2 ).

\section{Root morphology and plant growth}

The root pattern morphology of the three olive cultivars was observed at the end of the experiment. The root systems of 'Koroneiki' and 'Chondrolia Chalkidikis' were less branched and more lateral, and with less root hair development and density, than that of 'Kothreiki', which was richly-branched and with much greater root hair development and density. The differential root pattern morphology of the three olive cultivars influenced also the root dry weight (DW) as well as the ratio SDW/RDW, which differed between cultivars in the three soil types studied. Regarding the root growth and the ratio SDW/RDW for each olive cultivar among the three soil types used, differences were recorded only for 'Kothreiki', and not for 'Koroneiki' and 'Chondrolia Chalkidikis' (Table 3).

Chemical composition of vegetative tissues, total per plant nutrient content and nutrient use effciency

Differences $(p<0.05)$ concerning $\mathrm{Fe}, \mathrm{Zn}, \mathrm{Mg}$ and $\mathrm{P}$ leaf concentrations have been found among cultivars (Table 4). On the other hand, $\mathrm{P}$ concentration in the leaves of 'Koroneiki', as well as in the leaves of 'Chondrolia Chalkidikis', was lower when these cultivars were cultivated in the Gneiss schist soil, than in the other two soil types (Table 4). Concerning nutrient concentrations in root and total per plant nutrient content, in almost all soil types greater concentrations of all nutrients studied were recorded in the root system of 'Kothreiki', compared to those found in the root system of the other two olive cultivars (data not shown). Furthermore, greater total per plant content of all nutrients was found, in all

Table 1 - Physicochemical properties of the three soils.

\begin{tabular}{|c|c|c|c|c|c|c|c|c|c|c|c|c|c|c|}
\hline Soil & Sand & Clay & Loam & Texture & Organic matter & $\mathrm{pH}$ & $\mathrm{CaCO}_{3}$ & $\mathrm{P} /$ Olsen & $\mathrm{Ca}$ & $\mathrm{Mg}$ & K & $\mathrm{Mn}$ & $\mathrm{Fe}$ & $\mathrm{Zn}$ \\
\hline & & & $-\mathrm{gk}$ & & & & $\mathrm{g} \mathrm{kg}^{-1}$ & $\mathrm{mg} \mathrm{kg}^{-1}$ & $-n$ & $\mathrm{nol}_{\mathrm{c}} \mathrm{kg}$ & - & - & $\mathrm{g} \mathrm{kg-}$ & - \\
\hline Marl & $624 a$ & $228 \mathrm{a}$ & $148 b$ & SCL & $29 b$ & $7.6 \mathrm{a}$ & $35 b$ & $28 \mathrm{a}$ & 369 a & $22 \mathrm{a}$ & $14 \mathrm{~b}$ & $7 b$ & $3 a$ & $1.5 \mathrm{a}$ \\
\hline $\begin{array}{l}\text { Gneiss } \\
\text { schist }\end{array}$ & $684 a$ & $108 b$ & $208 a$ & SL & $17 c$ & $7.1 \mathrm{~b}$ & $13 \mathrm{c}$ & $15 b$ & 107 b & $22 \mathrm{a}$ & $12 \mathrm{~b}$ & $6 \mathrm{~b}$ & $5 a$ & $1.5 \mathrm{a}$ \\
\hline Peridotite & $524 b$ & $268 \mathrm{a}$ & $208 \mathrm{a}$ & $\mathrm{SCL}$ & $44 \mathrm{a}$ & $8.0 \mathrm{a}$ & $154 \mathrm{a}$ & $17 \mathrm{~b}$ & 362 a & $25 \mathrm{a}$ & $67 a$ & $12 \mathrm{a}$ & $4 a$ & $1 \mathrm{a}$ \\
\hline
\end{tabular}

The numbers are means of six replications. Means with different letters in each column are different (Duncan's multiple range test, $p<0.05)(S C L=S a n d y-C l a y-L o a m$; $S L=$ Sandy-Loam).

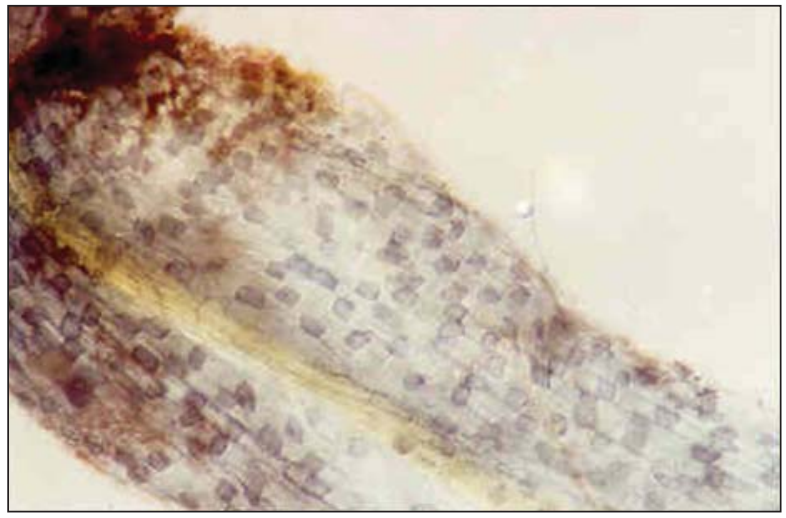

Figure 1 - Extended vesicles formation of Glomus sp. in the root system of the olive cultivar 'Koroneiki', when grown in the Marl soil.

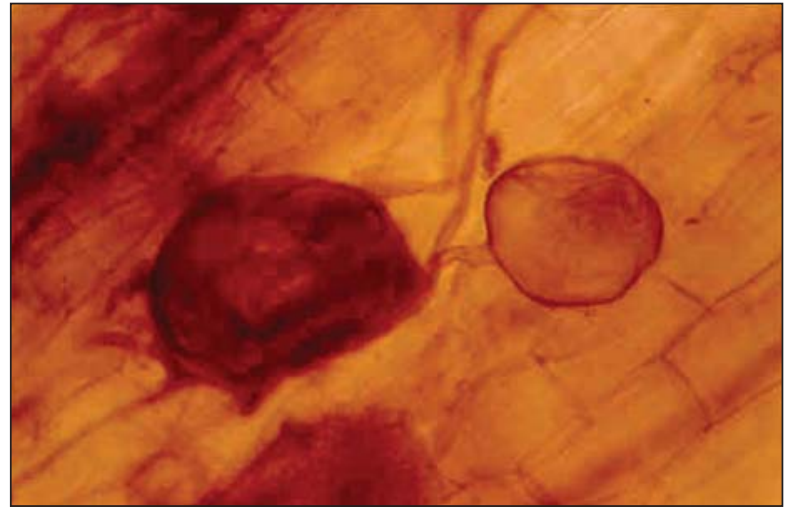

Figure 2 - Spore and Auxiliary cell of Gigaspora sp. in the root system of the olive cultivar 'Kothreiki', when grown in the Gneiss schist soil. 
Table 2 - Genus of arbuscular mycorrhiza fungus (AMF) colonizing the root system of the three olive cultivars, when each one of them is grown in three soil types, as well as percentage of root system colonization by AMF.

\begin{tabular}{lllc}
\hline Soil type / Olive cultivar & & AMF genus & Percentage of root system colonization (\%) \\
\hline \multirow{2}{*}{ Marl } & Koroneiki & Glomus sp. & $52 \mathrm{c}$ \\
& Kothreiki & Gigaspora sp. & $50 \mathrm{~cd}$ \\
& Chondrolia Chalkidikis & Gigaspora sp. & $73 \mathrm{a}$ \\
\hline \multirow{3}{*}{ Gneiss schist } & Koroneiki & Gigaspora sp. & $57 \mathrm{bc}$ \\
& Kothreiki & Gigaspora sp. & $53 \mathrm{c}$ \\
& Chondrolia Chalkidikis & Gigaspora sp. & $58 \mathrm{bc}$ \\
\hline \multirow{3}{*}{ Peridotite } & Koroneiki & Gigaspora sp. and Glomus sp. & $53 \mathrm{c}$ \\
& Kothreiki & Gigaspora sp. & $45 \mathrm{~d}$ \\
$P$ (main effect) & Chondrolia Chalkidikis & Gigaspora sp. & $65 \mathrm{ab}$ \\
$P$ (cultivar $\times$ soil type) & Olive cultivar & & $<0.05$ \\
\hline
\end{tabular}

The numbers are the means of five replications. The different letters between olive cultivars and soil types symbolize differences (post-hoc parametric test of Tukey, $p<0.05)$.

Table 3 - Plant growth parameters of the three olive cultivars studied, when grown in three soil types (DW = Dry Weight).

\begin{tabular}{|c|c|c|c|c|c|}
\hline \multicolumn{2}{|c|}{ Soil type / Olive cultivar } & Shoot length $(\mathrm{cm})$ & Total plant DW (g) & Root DW (g) & Shoot DW/ Root DW \\
\hline \multirow{3}{*}{ Marl } & Koroneiki & $98 \mathrm{~b}$ & $75 \mathrm{~b}$ & $20 \mathrm{c}$ & $2.70 \mathrm{~b}$ \\
\hline & Kothreiki & $120 a b$ & $125 \mathrm{a}$ & $47 a$ & $1.64 \mathrm{~d}$ \\
\hline & Chondrolia Chalkidikis & $119 a b$ & $67 \mathrm{bc}$ & $14 \mathrm{~d}$ & $3.79 \mathrm{a}$ \\
\hline \multirow{3}{*}{ Gneiss schist } & Koroneiki & $150 \mathrm{a}$ & $73 b$ & $20 \mathrm{c}$ & $2.65 b$ \\
\hline & Kothreiki & $84 \mathrm{bc}$ & $113 \mathrm{a}$ & $31 \mathrm{~b}$ & $2.87 \mathrm{~b}$ \\
\hline & Chondrolia Chalkidikis & $89 \mathrm{bc}$ & $59 \mathrm{c}$ & $12 \mathrm{~d}$ & $3.92 \mathrm{a}$ \\
\hline \multirow{3}{*}{ Peridotite } & Koroneiki & $79 \mathrm{c}$ & $73 b$ & $19 \mathrm{c}$ & $2.84 \mathrm{~b}$ \\
\hline & Kothreiki & $120 a b$ & $123 a$ & $40 a$ & $2.08 \mathrm{c}$ \\
\hline & Chondrolia Chalkidikis & $72 \mathrm{c}$ & $71 \mathrm{bc}$ & $14 \mathrm{~d}$ & $4.07 \mathrm{a}$ \\
\hline \multirow{2}{*}{$P$ (main effect) } & Olive cultivar & $<0.05$ & $<0.05$ & $<0.05$ & $<0.05$ \\
\hline & Soil type & $<0.05$ & $>0.05$ & $>0.05$ & $<0.05$ \\
\hline \multicolumn{2}{|c|}{$P$ (cultivar $\times$ soil type) } & $>0.05$ & $>0.05$ & $>0.05$ & $>0.05$ \\
\hline
\end{tabular}

The numbers are the means of five replications. The different letters between olive cultivars and soil types symbolize differences (post-hoc parametric test of Tukey, $p<0.05)$.

soils, in 'Kothreiki', than in the other two olive cultivars (Table 5). Use efficiency of almost all nutrients was lower in olive cultivar 'Kothreiki' than in the other ones, with the exception of $\mathrm{K}$ (Table 6).

\section{Discussion}

The three soil types had different physicochemical properties (Table 1) (Chatzistathis et al., 2010). In cultivars 'Chondrolia Chalkidikis' and 'Kothreiki' differences were observed concerning AMF abundance (root system colonization) between the Marl (73\%) and Gneiss schist (58 \%), and Gneiss schist (53\%) and Peridotite soils (45 $\%)$, respectively. The fact that in our investigation the highest AMF colonization was recorded in the Marl soil $(73 \%)$, compared to the other two ones, could be possibly correlated: (i) with the almost 3.5 times greater exchangeable Ca concentration recorded in that soil, compared to that found in the Gneiss schist soil or (ii) with the \% $\mathrm{CaCO}_{3}$ content $\left(35 \mathrm{~g} \mathrm{~kg}^{-1}\right.$, intermediate between those found in the Peridotite-154 $\mathrm{g} \mathrm{kg}^{-1}$ and Gneiss schist soil$13 \mathrm{~g} \mathrm{~kg}^{-1}$ ), (iii) with the texture of soils (AMF colonization may be possibly favored in the SCL soils, compared to the SL ones, like the Gneiss schist soil of our study), (iv) $\mathrm{pH}$ ( $\mathrm{pH}$ of the Marl soil was intermediate- 7.6, compared to the values of the other two soils), (v) the soil organic matter content (Table 1). A close relationship between soil organic matter and colonization rate of AMF is observed in salinized soils ( $\mathrm{Lu}$ et al., 2012). In addition to that, the colonization rate of AMF was promoted by the higher concentration of $\mathrm{HCO}_{3}{ }^{-}$(Lu et al., 2012). Ducic et al. (2009) found that the maximum mycorrhizal colonization in Pseudotsuga menziesii was found in a nutrient rich, than in a nutrient poor soil. According to Nilsson et al. (2005), along a nutrient gradient in coniferous forest soils, production of mycelia of AMF was highest in nutrient rich soils with high $\mathrm{pH}$. Our results for 'Chondrolia Chalkidikis' are partly in agreement to those reported by Nilsson et al. (2005) and Ducic et al. (2009), since the nutrient poorest soil, among the three studied, was that of Gneiss schist (Table 1), where it was recorded the lowest AMF abundance (58\%), compared to the other soils (Table 2).

For 'Koroneiki', no differences in AMF abundance were recorded between the three soil types, while for 'Kothreiki' the minimum AMF abundance was found in 
Table 4 - Leaf nutrient concentrations of three olive cultivars, in three soil types.

\begin{tabular}{|c|c|c|c|c|c|c|c|c|c|c|c|}
\hline \multicolumn{3}{|l|}{ Nutrient element } & Koroneiki & Kothreiki & $\begin{array}{l}\text { Chondrolia } \\
\text { Chalkidikis }\end{array}$ & Koroneiki & Kothreiki & $\begin{array}{l}\text { Chondrolia } \\
\text { Chalkidikis }\end{array}$ & Koroneiki & Kothreiki & $\begin{array}{l}\text { Chondrolia } \\
\text { Chalkidikis }\end{array}$ \\
\hline \multirow{2}{*}{\multicolumn{3}{|c|}{$\begin{array}{l}\text { Concentrations in Leaves } \\
\mathrm{Mn}\end{array}$}} & & Marl & & \multicolumn{3}{|c|}{ Gneiss schist } & \multicolumn{3}{|c|}{ Peridotite } \\
\hline & & & $23 b$ & $25 b$ & $27 a b$ & $27 a b$ & $28 \mathrm{ab}$ & $26 \mathrm{~b}$ & $29 a b$ & $30 a b$ & $36 a$ \\
\hline \multirow{2}{*}{$P$ (main effect) } & Cultivar & & & & & & $>0.05$ & & & & \\
\hline & Soil & & & & & & $>0.05$ & & & & \\
\hline$P$ (cultivar $\times$ soil) & & & & & & & $>0.05$ & & & & \\
\hline $\mathrm{Fe}$ & & $\stackrel{3}{8}$ & $68 c$ & $65 c$ & $73 b c$ & $84 a b$ & 72 bc & $81 b$ & $105 \mathrm{a}$ & $79 b$ & $77 \mathrm{bc}$ \\
\hline$P$ (main effect) & Cultivar & खa & & & & & $<0.05$ & & & & \\
\hline & Soil & $\sum_{\Sigma}^{0}$ & & & & & $<0.05$ & & & & \\
\hline$P($ cultivar $\times$ soil $)$ & & & & & & & $>0.05$ & & & & \\
\hline $\mathrm{Zn}$ & & & $19 \mathrm{bc}$ & $22 \mathrm{ab}$ & $15 c$ & $26 \mathrm{ab}$ & $23 \mathrm{ab}$ & $16 \mathrm{c}$ & $28 \mathrm{a}$ & $26 a b$ & 20 bc \\
\hline \multirow{2}{*}{$P$ (main effect) } & Cultivar & & & & & & $<0.05$ & & & & \\
\hline & Soil & & & & & & $>0.05$ & & & & \\
\hline$P$ (cultivar $\times$ soil) & & & & & & & $>0.05$ & & & & \\
\hline $\mathrm{Ca}$ & & & $1.39 a b$ & $1.35 a b$ & $1.16 \mathrm{ab}$ & $1.32 \mathrm{ab}$ & $1.23 \mathrm{ab}$ & $1.03 \mathrm{~b}$ & $1.55 \mathrm{a}$ & $1.32 \mathrm{ab}$ & $1.11 \mathrm{~b}$ \\
\hline \multirow{2}{*}{$P$ (main effect) } & Cultivar & & & & & & $>0.05$ & & & & \\
\hline & Soil & & & & & & $>0.05$ & & & & \\
\hline$P$ (cultivar $\times$ soil) & & & & & & & $>0.05$ & & & & \\
\hline Mg & & & $0.12 a b$ & $0.09 \mathrm{c}$ & $0.10 \mathrm{bc}$ & $0.15 a$ & $0.10 c$ & $0.11 b c$ & $0.15 \mathrm{a}$ & $0.10 \mathrm{bc}$ & $0.12 a b$ \\
\hline \multirow{2}{*}{$P$ (main effect) } & Cultivar & & & & & & $<0.05$ & & & & \\
\hline & Soil & & & & & & $>0.05$ & & & & \\
\hline$P$ (cultivar $\times$ soil) & & $\stackrel{\circ}{2}$ & & & & & $>0.05$ & & & & \\
\hline K & & $\dot{\xi}$ & $1.20 \mathrm{a}$ & $1.06 a b$ & $1.07 \mathrm{ab}$ & $1.25 \mathrm{a}$ & $1.08 \mathrm{ab}$ & $1.06 \mathrm{ab}$ & $1.20 \mathrm{a}$ & $1.03 \mathrm{~b}$ & $1.14 \mathrm{a}$ \\
\hline \multirow{2}{*}{$P$ (main effect) } & Cultivar & & & & & & $>0.05$ & & & & \\
\hline & Soil & & & & & & $>0.05$ & & & & \\
\hline$P$ (cultivar $\times$ soil) & & & & & & & $>0.05$ & & & & \\
\hline$P$ & & & $0.20 \mathrm{bc}$ & $0.30 \mathrm{a}$ & $0.23 \mathrm{~b}$ & $0.17 c$ & $0.30 \mathrm{a}$ & $0.13 d$ & $0.23 \mathrm{~b}$ & $0.22 \mathrm{~b}$ & $0.21 \mathrm{~b}$ \\
\hline \multirow{2}{*}{$P$ (main effect) } & Cultivar & & & & & & $<0.05$ & & & & \\
\hline & Soil & & & & & & $<0.05$ & & & & \\
\hline$P$ (cultivar $\times$ soil) & & & & & & & $>0.05$ & & & & \\
\hline
\end{tabular}

The numbers are the means of five replications. The different letters between olive cultivars and soil types symbolize differences (post-hoc parametric test of Tukey, $p<0.05)$.

the Peridotite soil (Table 2). The fact that each of the three olive cultivars studied behaved differently concerning root system colonization means that AMF abundance depended also on olive cultivar; this is very important because, according to our knowledge, it is the first report showing that differences in the ability to form AMF exist among different varieties of olive trees. Generally, AMF colonization of olive plants (45-73\%) was satisfactory and greater than that found for other species, such as maize (Zea mays) (15-45 \%) (Hu et al., 2009), Citrus (19-51 \%) (Wu and Zou, 2010), different woody native of the Atlantic rain forest species (34-62 \%) (Pasqualini et al., 2007), P. menziesii (5-30 \%) (Ducic et al., 2008; 2009), rice (Oryza sativa) (14 \%) (Xiao et al., 2010) and pelargonium plants (Pelargonium peltatum) (up to $36 \%$ ) (Perner et al., 2007). Conversely, the roots of five species of stoloniferous plants were colonized by AMF, with colonization percentage varying from 40 to $90 \%$ (Sudova, 2009). Furthermore, mycorrhizal colonization of tomatoes roots (Solanum lycopersicum) roots under low, medium and high $\mathrm{Zn}$ concentrations varied from 60 to $75 \%$ (Cavagnaro et al., 2010).
Concerning the influence of genotype on AMF abundance, in two of the three soil types (Marl and Peridotite) greater root system colonization was recorded in cultivar 'Chondrolia Chalkidikis' (Table 2). Ducic et al. (2009), who studied the mycorrhizal communities in two varieties of $P$. menziesii in different forest soils, found that the abundance of ectomycorrhizas was greater on the root of cultivar 'Menziesii', than on the root of 'Glauca', and that the physiology of the host tree, as well as soil properties, were the decisive factors for formation and abundance of ectomycorrhiza. In our experiment, Glomus sp. colonized only the root system of cultivar 'Koroneiki', and not that of the other two ones (Figure 1). On the other hand, Gigaspora sp. colonized the root system of all cultivars studied, depending also on soil type (Figure 2). However, different species of the same genus (Gigaspora sp.) might colonize the root system of the two above mentioned olive cultivars', and this possible differential colonization could be responsible for the differences found in AMF abundance between these two cultivars (differential colonization capacity among species of the same 
Table 5 - Total plant nutrient content of the three olive cultivars, in three soils.

\begin{tabular}{|c|c|c|c|c|c|c|c|c|c|c|c|}
\hline \multirow[t]{2}{*}{ Total plant content } & & & Koroneiki & Kothreiki & $\begin{array}{l}\text { Chondrolia } \\
\text { Chalkidikis }\end{array}$ & Koroneiki & Kothreiki & $\begin{array}{l}\text { Chondrolia } \\
\text { Chalkidikis }\end{array}$ & Koroneiki & Kothreiki & $\begin{array}{l}\text { Chondrolia } \\
\text { Chalkidikis }\end{array}$ \\
\hline & & & \multicolumn{3}{|c|}{ Marl } & \multicolumn{3}{|c|}{ Gneiss schist } & \multicolumn{3}{|c|}{ Peridotite } \\
\hline$\overline{\mathrm{Mn}}$ & & & $1.94 \mathrm{~d}$ & $5.89 a$ & $1.43 \mathrm{de}$ & $2.79 \mathrm{c}$ & $4.12 \mathrm{~b}$ & $1.07 \mathrm{e}$ & $2.11 \mathrm{~cd}$ & $3.65 b$ & $1.70 \mathrm{~d}$ \\
\hline \multirow{2}{*}{$P$ (main effect) } & Cultivar & & & & & & $<0.05$ & & & & \\
\hline & Soil & & & & & & $<0.05$ & & & & \\
\hline$P$ (cultivar $\times$ soil) & & & & & & & $>0.05$ & & & & \\
\hline $\mathrm{Fe}$ & & & $25 d$ & $278 a$ & $18 \mathrm{e}$ & $77 c$ & $142 \mathrm{~b}$ & $18 \mathrm{e}$ & $27 d$ & $103 b$ & $24 d$ \\
\hline \multirow{2}{*}{$P$ (main effect) } & Cultivar & & & & & & $<0.05$ & & & & \\
\hline & Soil & & & & & & $<0.05$ & & & & \\
\hline$P$ (cultivar $\times$ soil) & & & & & & & $>0.05$ & & & & \\
\hline $\mathrm{Zn}$ & & & $1.38 \mathrm{~b}$ & $3.53 \mathrm{a}$ & $0.95 b c$ & $1.61 \mathrm{~b}$ & $3.46 \mathrm{a}$ & $0.76 \mathrm{c}$ & $1.59 \mathrm{~b}$ & $3.66 \mathrm{a}$ & $1.35 b$ \\
\hline \multirow{2}{*}{$P$ (main effect) } & Cultivar & & & & & & $<0.05$ & & & & \\
\hline & Soil & & & & & & $>0.05$ & & & & \\
\hline$P$ (cultivar $\times$ soil) & & & & & & & $>0.05$ & & & & \\
\hline $\mathrm{Ca}$ & & & $677 b$ & $1397 a$ & $585 \mathrm{bc}$ & $618 b$ & 1387 a & $466 \mathrm{c}$ & $698 b$ & $1320 \mathrm{a}$ & $586 \mathrm{bc}$ \\
\hline \multirow{2}{*}{$P$ (main effect) } & Cultivar & 3 & & & & & $<0.05$ & & & & \\
\hline & & $\vec{\infty}$ & & & & & $>0.05$ & & & & \\
\hline$P$ (cultivar $\times$ soil) & & & & & & & $>0.05$ & & & & \\
\hline Mg & & & $80 \mathrm{bc}$ & $168 \mathrm{a}$ & $71 \mathrm{c}$ & $101 \mathrm{~b}$ & $174 a$ & $69 c$ & $85 b c$ & $170 \mathrm{a}$ & $85 b c$ \\
\hline \multirow{2}{*}{$P$ (main effect) } & Cultivar & & & & & & $<0.05$ & & & & \\
\hline & Soil & & & & & & $>0.05$ & & & & \\
\hline$P$ (cultivar $\times$ soil) & & & & & & & $>0.05$ & & & & \\
\hline K & & & $582 \mathrm{~b}$ & $1120 \mathrm{a}$ & $556 \mathrm{bc}$ & $586 b$ & 1129 a & $469 c$ & $591 b$ & 1063 a & $630 \mathrm{~b}$ \\
\hline \multirow{2}{*}{$P$ (main effect) } & Cultivar & & & & & & $<0.05$ & & & & \\
\hline & Soil & & & & & & $>0.05$ & & & & \\
\hline$P$ (cultivar $\times$ soil) & & & & & & & $>0.05$ & & & & \\
\hline$P$ & & & $118 b$ & $315 a$ & $97 \mathrm{~b}$ & $78 c$ & $243 a$ & $56 d$ & $120 b$ & $255 a$ & $117 b$ \\
\hline \multirow{2}{*}{$P$ (main effect) } & Cultivar & & & & & & $<0.05$ & & & & \\
\hline & Soil & & & & & & $<0.05$ & & & & \\
\hline$P$ (cultivar $\times$ soil) & & & & & & & $>0.05$ & & & & \\
\hline
\end{tabular}

The numbers are the means of five replications. The different letters between olive cultivars and soil types symbolize differences (post-hoc parametric test of Tukey, $p<0.05)$.

Table 6 - Nutrient use efficiency of the three olive cultivars studied, when grown in three soil types (UE = Use efficiency).

\begin{tabular}{|c|c|c|c|c|c|c|c|c|}
\hline \multicolumn{2}{|c|}{ Soil type / Olive cultivar } & MnUE & FeUE & ZnUE & CaUE & MgUE & KUE & PUE \\
\hline & & \multicolumn{7}{|c|}{ g. dry weight per mg of micro- or macro- nutrient __ } \\
\hline \multirow{4}{*}{ Marl } & Koroneiki & $38.66 \mathrm{~b}$ & $3.00 \mathrm{a}$ & $54.35 \mathrm{~b}$ & $0.11 \mathrm{a}$ & $0.94 \mathrm{a}$ & $0.13 \mathrm{a}$ & $0.64 \mathrm{~b}$ \\
\hline & Kothreiki & $21.22 \mathrm{~d}$ & $0.45 \mathrm{c}$ & $35.42 \mathrm{c}$ & $0.09 \mathrm{a}$ & $0.74 \mathrm{~b}$ & $0.11 \mathrm{a}$ & $0.40 \mathrm{c}$ \\
\hline & Chondrolia Chalkidikis & $46.85 a$ & $3.73 a$ & $70.55 a$ & $0.11 \mathrm{a}$ & $0.94 \mathrm{a}$ & $0.12 \mathrm{a}$ & $0.69 b$ \\
\hline & Koroneiki & $26.16 \mathrm{c}$ & $0.95 b$ & $45.34 \mathrm{bc}$ & $0.12 \mathrm{a}$ & $0.72 b$ & $0.12 \mathrm{a}$ & $0.94 \mathrm{a}$ \\
\hline \multirow[t]{2}{*}{ Gneiss schist } & Kothreiki & $27.43 \mathrm{c}$ & $0.80 \mathrm{~b}$ & $32.66 \mathrm{c}$ & $0.08 b$ & $0.65 b$ & $0.10 \mathrm{a}$ & $0.47 c$ \\
\hline & Chondrolia Chalkidikis & 55.15 a & $3.28 \mathrm{a}$ & 77.63 a & $0.13 a$ & $0.86 \mathrm{a}$ & $0.13 a$ & $1.05 \mathrm{a}$ \\
\hline \multirow{3}{*}{ Peridotite } & Koroneiki & $34.60 \mathrm{bc}$ & $2.70 \mathrm{a}$ & $45.92 b c$ & $0.10 a$ & $0.86 a$ & $0.12 a$ & $0.61 b$ \\
\hline & Kothreiki & $33.70 \mathrm{bc}$ & $1.19 \mathrm{~b}$ & $33.61 \mathrm{c}$ & $0.09 a$ & $0.72 b$ & $0.12 \mathrm{a}$ & $0.48 c$ \\
\hline & Chondrolia Chalkidikis & $41.77 b$ & $2.96 \mathrm{a}$ & $52.60 \mathrm{~b}$ & $0.12 \mathrm{a}$ & $0.84 a b$ & $0.11 \mathrm{a}$ & $0.61 b$ \\
\hline \multirow{2}{*}{$P$ (main effect) } & Olive cultivar & $<0.05$ & $<0.05$ & $<0.05$ & $>0.05$ & $<0.05$ & $>0.05$ & $<0.05$ \\
\hline & Soil type & $>0.05$ & $<0.05$ & $>0.05$ & $>0.05$ & $>0.05$ & $>0.05$ & $<0.05$ \\
\hline \multicolumn{2}{|c|}{$P$ (cultivar $\times$ soil type $)$} & $>0.05$ & $>0.05$ & $>0.05$ & $>0.05$ & $>0.05$ & $>0.05$ & $>0.05$ \\
\hline
\end{tabular}

The numbers are the means of five replications. The different letters between olive cultivars and soil types symbolize differences (post-hoc parametric test of Tukey, $p<0.05)$.

AMF genus). This hypothesis, however, needs further investigation and elucidation. In one case the root system of 'Koroneiki' was colonized by both Glomus sp. and Gigaspora sp., when it was grown on the Peridotite soil. It is possible that the properties of the Peridotite soil favored the double AMF colonization in the root system of 'Koroneiki', compared to the other two soil types. Plants under field conditions may be colonized 
by many AMF taxa and the outcomes of these symbioses are determined by interactions between plant, fungal genomes and environmental conditions (e.g. soil pH and P) (Smith et al., 2011). Jin et al. (2013) found that the mixed species AMF inoculant $(G$. irregulare, $G$. mosseae and $G$. clarum) performed better than the single species $G$. irregulare alone by promoting mycorrhizal colonization and field pea (Pisum sativum L.) biomass.

The differential root system morphology among the three olive cultivars could be possibly ascribed to the differential root system colonization by AMF among the three olive cultivars. Citernesi et al. (1998) found that inoculation with AMF G. mosseae affected root system morphology of olive plants and that such an increase in branching could be partly due to a better mineral nutrition of mycorrhizal plants. Citernesi et al. (1998), however, did not compare the influence of different AMF genus/species on root system morphology. The root system of 'Kothreiki' was richly-branched and with much greater root hair development and density $(p<0.05)$ due to the better mineral nutrition of their plants (Tables 4 and 5).

Hill et al. (2010) refer that AMF colonization of Trifolium subterraneum increased the absorptive surface of root system (density of root hairs) and the volume of soil that can be explored by the root system, as well as simultaneously increased P uptake. Orfanoudakis et al. (2010) found that both Gigaspora rosea and Frankia increased root branching in Alnus glutinosa seedlings, and the effects were greater when both were present. In contrast to that, both $G$. rosea and Frankia decreased root hair numbers markedly, and the effects on root hair development were not a consequence of phosphorus levels, as $\mathrm{P}$ levels were not significantly changed in seedlings colonized by G. rosea or nodulated by Frankia. Finally, AMF increased and ameliorated the root system architecture traits (taproot length, total length, projected and surface root areas, volume and number of first, second and third order lateral roots e.t.c.) of Citrus plants (Wu et al., 2012; Wu et al., 2013).

Differences have been observed concerning the values of RDW, as well as those of the ratio SDW/RDW among olive cultivars grown in the same soil type (Table 3). Orfanoudakis et al. (2010) found that root growth of Alnus glutinosa seedlings inoculated with Frankia sp. was slightly favored over shoot development, influencing the SDW/RDW ratio. In the present study, in all the three soils studied, the SDW/RDW values of 'Chondrolia Chalkidikis' were greater (3.79-4.07), compared to those ones of the other two cultivars (1.64-2.87), and this coincided with the greatest AMF abundance in the root system of that cultivar (it varied between $58 \%$ and 73 $\%)$, compared to that found in the other two olive cultivars (it varied from $45 \%$ to $57 \%$; Table 2). Therefore, it seems possible that the greatest AMF abundance in the root system of 'Chondrolia Chalkidikis' influenced negatively root growth over that of shoot, and consequently influenced positively the ratio SDW/RDW.
Cavagnaro et al. (2008) found that AMF colonization of Solanum lycopersicum plants decreased root biomass, something which partially agrees with our data for olive plants, since, in each of the three soil types studied, 'Chondrolia Chalkidikis' had the lowest root biomass values (Table 3). Mycorrhizal maize plants had lower root to shoot ratios, than the non-mycorrhizal ones (Sheng et al., 2009). Carretero et al. (2009) also found that the biomass distribution between shoot and root of micropropagated cassava clones changed by AMF symbiosis with $G$. intraradices. Nzanza et al. (2012) did not observe differences in dry shoot/root ratio for $S$. lycopersicum plants between single AMF colonization by G. mosseae and double one (by both G. mosseae and Trichoderma harzianum).

In this study, other possible reasons that may explain the differences in shoot/root growth between the three olive cultivars could be genetic ones (inherent growth capacities), or differences in the photosynthetic rate among the three cultivars, or even differential distribution of carbohydrates between root system and shoot. Indeed, in other experiments conducted with the olive cultivars 'Picual' and 'Koroneiki', we found differences among their photosynthetic rates (Chatzistathis et al., 2012). For the same reasons could be also ascribed the fact that the total dry weight of 'Kothreiki' plants was greater, than that of the other two cultivars (Table 3). According to Ducic et al. (2009), differences in biomass production of two Douglas fir varieties under the same soil conditions was mainly the result of differences in their inherent growth capacities and not of different AMF colonization rates. Wu and Zou (2010), Hajiboland et al. (2007), and Caravaca et al. (2003) found that AMF colonization with $G$. mosseae and $G$. intraradices had beneficial effects on photosynthesis and stomatal conductance in Citrus seedlings, S. lycopersicum and olive plants, respectively. However, the greatest total plant weight, which was that of 'Kothreiki', coincided with the lowest AMF abundance found in the root system of that cultivar in each of the three soil types (Table 2), while the lowest total dry weight of plants, which was that of 'Chondrolia Chalkidikis', coincided with the greatest AMF abundance in its root system (Tables 2 and 3).

Ducic et al. (2008) found that the colonization of two $P$. menziesii cultivars with $R$. subareolatus suppressed plant growth, despite positive effects of mycorrhizas on plant P nutrition, while Cavagnaro et al. (2008), Xiao et al. (2010) and Orfanoudakis et al. (2004) found that AMF colonization did not affect the above ground biomass of S. lycopersicum, rice and Alnus glutinosa plants, respectively, compared to the control ones. According to Sudova (2009), plant growth response of five stoloniferous species to AMF inoculation with three species of Glomus varied widely from negative to positive. In our research, plant growth parameters (main shoot length, total plant weight, root weight, shoot/root dry weight) of the three olive cultivars were, in some cases, positively correlated with AMF abundance, while in some others were negatively correlated, or even non correlated, therefore, a 
conclusion about the correlation between plant growth and AMF abundance is not possible to be retrieved.

Generally, there are many cases where moderate, or even negative, effects under AMF inoculation occur. Such findings occur when AMF applied under natural conditions in the field and in moderate or nutrient rich sites or soils (Orfanoudakis, personal communication). However, the majority of researchers refer that AMF inoculation/colonization influenced positively total plant dry weight, as well as other growth parameters of many plant species (Pasqualini et al., 2007; Dag et al., 2009; Sheng et al., 2009; Shokri and Maadi, 2009). Dag et al. (2009) refer that the intensity of response in the increases of height and biomass of 12 commercial olive cultivars inoculated with $G$. mosseae and $G$. intraradices was highly cultivar-specific.

Regarding nutrient uptake, higher total plant contents of all nutrients have been recorded in the plants of the olive cultivar 'Kothreiki', compared to those found in the plants of the other two cultivars (Table 5). This probably happened due to the differential root system morphology of 'Kothreiki'. Previously, it was found that 'Kothreiki' absorbed greater amount of all nutrients, compared to 'Koroneiki' (Chatzistathis et al., 2009). Leaf $\mathrm{Fe}$ concentration in the Peridotite soil was greater in 'Koroneiki', compared to the other two ones (Table 4), and this finding could be possibly ascribed to the double colonization of the root system of that cultivar by AMF Gigaspora sp. and Glomus sp. In that case, Gigaspora sp. and Glomus sp. might have a synergistic effect on Fe uptake by olive plants. However, all these hypotheses need additional research in the near future in order to be verified. Jin et al. (2013) found that the mixed species AMF inoculant (G. irregulare, G. mosseae and $G$. clarum) performed better than the single species G. irregulare alone in promoting $\mathrm{P}$ uptake by $P$. sativum plants (Tables 4 and 5). Jin et al. (2013) worked with inoculation treatments of species of Glomus, while in our study we worked under natural conditions (without treatments); in addition, the double colonization in our research occurred with different AMF genera (Glomus sp. and Gigaspora sp.) and not with different species of the same genus.

Differences in leaf $\mathrm{Mg}, \mathrm{P}$ and $\mathrm{Zn}$ concentrations have been found between the three cultivars, in all soil types (Table 4), which could be also possibly ascribed to the differential AMF colonization (Table 2). Several researchers have found that AMF inoculation/colonization increased the uptake of $\mathrm{Zn}, \mathrm{Mn}, \mathrm{Mg}$ and $\mathrm{P}$ in different plant species (Perner et al., 2007; Pasqualini et al., 2007; Cavagnaro, 2008; Ducic et al., 2008; Ducic et al., 2009; Hu et al., 2009; Shokri and Maadi, 2009; Sudova, 2009; Richard et al., 2010; Wu and Zou, 2010). Iron concentration in the leaves of cultivars 'Kothreiki' and 'Chondrolia Chalkidikis' was negatively correlated with AMF abundance $(r=-0.49$ and -0.79 , respectively, data not shown), while those of $\mathrm{P}$ in the same two cultivars and $\mathrm{Mn}$ in 'Koroneiki' were positively correlated with AMF colo- nization $(\mathrm{r}=0.78,0.80$, and 0.92 , respectively, data not shown). Finally, total $\mathrm{Mn}, \mathrm{Fe}, \mathrm{Mg}$ and $\mathrm{P}$ contents were, in most cases, positively correlated with AMF colonization ( $\mathrm{r}=0.44-0.91$, data not shown).

Generally, nutrient use efficiency (NUE) on a whole-plant basis links several processes and gives a global response of plants to nutrient stress (Chapin and Van Cleve, 1991). In our study, phosphorus use efficiency (PUE) was lower $(p<0.05)$ in cultivar 'Kothreiki' (Table 6), where lower AMF abundance (Table 2), compared to the other two cultivars, was found. Ducic et al. (2009) found that PUE was negatively correlated with the abundance of AMF in two cultivars of P. menziessi. Here, only in cultivar 'Chondrolia Chalkidikis' PUE was negatively correlated with the abundance of AMF $(\mathrm{r}=-0.62$, data non-shown), while in 'Koroneiki' it was positively correlated with AMF colonization ( $\mathrm{r}=0.83$, data not shown).

As previously discussed, the reasons for the existing PUE differences among the olive cultivars could be genetic. Manganese use efficiency (MnUE) in the Marl and Gneiss schist soils, as well as those of iron and zinc in all soils studied, were higher $(p<0.05)$ in 'Chondrolia Chalkidikis' plants, compared to those of the other two cultivars (Table 6). Manganese use efficiency in all three olive cultivars was negatively correlated with AMF abundance ( $\mathrm{r}$ values varied between -0.50 and -0.82 , data not shown). Furthermore, iron use efficiency (FeUE) was negatively correlated with AMF colonization in cultivars 'Koroneiki' and 'Kothreiki' $(\mathrm{r}=-0.89$ and -0.59, respectively, data not shown) and positively in 'Chondrolia Chalkidikis' ( $\mathrm{r}=0.52$, data not shown).

Rengel (2001) reviewed genotypic differences in micronutrient use efficiency of many crops and stated that micronutrient-efficient genotypes were capable of increasing the available soil micronutrient pools by changing chemical and microbiological properties of the rhizosphere, as well as by producing thinner and longer roots and by having more efficient uptake and transport mechanisms. In our research, the root morphology of 'Kothreiki' was richly-branched and with much greater root hair development and density, compared to those of the other two cultivars. Furthermore, its root system colonization by AMF, in the Marl and Peridotite soils, was lower to that found in the other two ones (Table 2).

Mycorrhiza has the ability to modify the properties of the rhizosphere and to affect the morphology of root system, as for example found by Citernesi et al., (1998) for plants of three Italian olive cultivars. All these findings considered together is a strong indication for 'Chondrolia Chalkidikis' that its ability to use more efficiently the three micronutrients studied is more likely attributed to differential AMF colonization of the root system (greater AMF colonization and different AMF genera colonizing its root system, compared to that colonizing the root system of 'Koroneiki'. Furthermore, different species of Gigaspora is possible to colonize its root system, compared to that colonizing the root system of 'Chondrolia 
Chalkidikis'). Finally, magnesium use efficiency (MgUE) was also negatively correlated with AMF abundance in cultivars 'Koroneiki' and 'Kothreiki' $/ \mathrm{r}=-0.91$ and -0.527, respectively, data not shown), but not in cultivar 'Chondrolia Chalkidikis' ( $\mathrm{r}=0.64$, data not shown).

\section{Conclusions}

Gigaspora sp. was found to colonize the root system of the three olive cultivars studied, while Glomus sp. colonized only the root system of 'Koroneiki'. Furthermore, different colonization percentages of their root system by AMF were recorded under the same soil conditions. The physiology of the host tree, as well as soil properties could be the decisive factors for the formation and abundance of AMF among cultivars. The existing differences in root morphology, plant growth parameters, as well as nutrient uptake and use efficiency between cultivars under the same soil conditions enhance the possibility and provide strong indications that they could be attributed to the differences in AMF colonization.

\section{References}

Alifragis, D.A.; Papamichos, N. 1995. Soil Sampling and Chemical Analyses of Forest Soils and Vegetative Tissues. Dedousis Publications, Thessaloniki, Greece (in Greek).

Allison, L.E. 1965. Organic matter. p. 1367-1378. In: Black, C.A., ed. Methods of soil analysis. American Society of Agronomy, Madison, WI, USA

Bates, R.G. 1964. Determination of pH: theory and practice. John Wiley, New York, NY, USA.

Bolandnazar, S.; Aliasgarzad, N.; Neishabury, M.R.; Chaparzadeh, N. 2007. Mycorrhizal colonization improves onion (Allium cepa L.) yield and water use efficiency under water deficit condition. Scientia Horticulturae 114: 11-15.

Bower, C.A.; Reitemeier, R.F.; Firemann, M. 1952. Exchangeable cation analysis of saline and alkali soils. Soil Science 73: 251261.

Caravaca, F.; Diaz, E.; Barea, J.M.; Azcon-Aguilar, C.; Roldan, A. 2003. Photosynthetic and transpiration rates of Olea europaea subsp. sylvestris and Rhamnus lycioides as affected by water deficit and mycorrhiza. Biologia Plantarum 46: 637-639.

Carretero, C.L.; Cantos, M.; Garcia, J.L.; Azcon, R.; Troncoso, A. 2009. Growth responses of micropropagated cassava clones as affected by Glomus intraradices colonization. Journal of Plant Nutrition 32: 261-273

Castillo, P.; Nico, A.I.; Azcon-Aguilar, C.; Del Rio Rincon, C.; Calvet, C.; Jimenez-Diaz, R.M. 2006. Protection of olive planting stocks against parasitism of root-knot nematodes by arbuscular mycorrhizal fungi. Plant Pathology 55: 705-713.

Cavagnaro, T.R. 2008. The role of arbuscular mycorrhizas in improving plant zinc nutrition under low soil zinc concentrations: a review. Plant and Soil 304: 315-325.

Cavagnaro, T.R.; Langley, A.J.; Jackson, L.E.; Smukler, S.M.; Koch, G.W. 2008. Growth, nutrition, and soil respiration of a mycorrhiza-defective tomato mutant and its mycorrhizal wildtype progenitor. Functional Plant Biology 35: 228-235.
Cavagnaro, T.R.; Dickson, S.; Smith, F.A. 2010. Arbuscular mycorrhizas modify plant responses to soil zinc addition. Plant and Soil 329: 307-313.

Chapin, F.S.; Van Cleve, K. 1991. Approaches to studying nutrient uptake, use and loss in plants. p. 185-207. In: Pearcy, R.W.; Ehleringer, J.R.; Mooney, H.A.; Rundel, P.W., eds. Plant physiological ecology-field methods and instrumentation. Chapman and Hall, New York, NY, USA.

Chatzistathis, T.; Therios, I.; Alifragis, D. 2009. Differential uptake, distribution within tissues, and use efficiency of Manganese, Iron and Zinc by olive cultivars 'Kothreiki' and 'Koroneiki'. HortScience 44: 1994-1999.

Chatzistathis, T.; Therios, I.; Alifragis, D.; Dimassi, K. 2010. Effect of sampling time and soil type on $\mathrm{Mn}, \mathrm{Fe}, \mathrm{Zn}, \mathrm{Ca}, \mathrm{Mg}, \mathrm{K}$ and $\mathrm{P}$ concentrations of olive (Olea europaea L., cv.'Koroneiki') leaves. Scientia Horticulturae 126: 291-296.

Chatzistathis, T.; Papadakis, I.; Therios, I.; Patakas, A.; Giannakoula, A.; Menexes, G. 2012. Differential response of two olive cultivars to excess manganese. Journal of Plant Nutrition 35: 784-804.

Citernesi, A.S. ; Vitagliano, C. ; Giovannetti, M. 1998. Plant growth and root system morphology of Olea europaea L. rooted cuttings as influenced by arbuscular mycorrhizas. Journal of Horticultural Science and Biotechnology 73: 647-654.

Dag, A.; Yermiyahu, U.; Ben-Gal, A.; Zipori, I.; Kapulnik, Y. 2009. Nursery and post transplant field response of olive trees to arbuscular mycorrhizal fungi in an arid region. Crop Pasture Science 60: 427-433.

Doubkova, P.; Suda, J.; Sudova, R. 2012. The symbiosis with arbuscular mycorrhiza fungi contributes to plant tolerance to serpentine edaphic stress. Soil Biology and Biochemistry 44: 56-64.

Ducic, T.; Parlade, J.; Polle, A. 2008. The influence of the ectomycorrhizal fungus Rhizopon subareolatus on growth and nutrient element localization in two varieties of Douglas fir (Pseudotsuga menziesii var. menziesii and var. glauca) in response to manganese stress. Mycorrhiza 18: 227-239.

Ducic, T.; Berthold, D.; Langenfeld-Heyser, R.; Beese, F.; Polle, A. 2009. Mycorrhizal communities in relation to biomass production and nutrient use efficiency in two varieties of Douglas fir (Pseudotsuga menziesii var. menziesii and var. glauca) in different forest soils. Soil Biology and Biochemistry 41: 742-753.

Hill, J.O.; Simpson, R.J.; Ryan, M.H.; Chapman, D.F. 2010. Root hair morphology and mycorrhizal colonization of pasture species in response to phosphorus and nitrogen nutrition. Crop Pasture Science 61: 122-131.

Hu, J.; Lin, X.; Wang, J.; Dai, J.; Cui, X.; Chen, R.; Zhang, J. 2009. Arbuscular mycorrhizal fungus enhances crop yield and P-uptake of maize (Zea mays L.): A field case study on a sandy loam soil as affected by long-term P-deficiency fertilization. Soil Biology and Biochemistry 41: 2460-2465.

Jin, H.; Germida, J.J.; Walley, F.L. 2013. Impact of arbuscular mycorrhizal fungal inoculants on subsequent arbuscular mycorrhizal fungi colonization in pot cultured field pea (Pisum sativum L.). Mycorrhiza 23: 45-59.

Klute, A. 1986. Method of Soil Analysis. p. 404-408. In: Klute A., ed. Physical and mineralogical methods. American Society of Agronomy, Soil Science Society of America,. Madison, WI, USA. 
Koske, R.E.; Gemma, J.N. 1989. A modified procedure for staining roots to detect VA mycorrhizas. Mycological Research 92: 486505.

Lu, X.; Du, Q.; Yan, Y.; Ma, K.; Wang, Z.; Jiang, Q. 2012. Effects of soil rhizosphere microbial community and soil factors on arbuscular mycorrhizal fungi in different salinized soils. Acta Ecologica Sinica 32: 4071-4078.

Malusa, E.; Sas-Paszt, L.; Popinska, W.; Zurawich, E. 2007. The effect of a substrate, containing arbuscular mycorrhizal fungi, and rhizosphere microorganisms (Trichoderma, Bacillus, Pseudomonas and Streptomyces), and foliar fertilization on growth response and rhizosphere $\mathrm{pH}$ of three strawberry cultivars. International Journal of Fruit Science 6: 25-41.

Marulanda, A.; Porcel, R.; Barea, J.M.; Azcon, R. 2007. Drought tolerance and antioxidant activities in lavender plants colonized by native drought-tolerant or drought-sensitive Glomus species. Microbial Ecology 54: 543-552.

Nilsson, L.O.; Gieseler, R.; Baath, E.; Wallander, H. 2005. Growth and biomass of mycorrhizal mycelia in coniferous forest along short natural nutrient gradients. New Phytologist 165: 613622.

Nzanza, B.; Marais, D.; Soundy, P. 2012. Response of tomato (Solanum lycopersicum L.) to nursery inoculation with Trichoderma harzianum and arbuscular mycorrhizal fungi under field conditions. Acta Agriculturae Scandinavica Section B-Soil and Plant Science 62: 209-215.

Orfanoudakis, M.Z.; Hooker, J.E.; Wheeler, C.T. 2004. Early interactions between arbuscular mycorrhizal fungi and Frankia during colonization and root nodulation of Alnus glutinosa. Symbiosis 36: 69-82.

Orfanoudakis, M.; Wheeler, C.T.; Hooker, J.E. 2010. Both the arbuscular mycorrhizal fungus Gigaspora rosea and Frankia increase root system branching and reduce root hair frequency in Alnus glutinosa. Mycorrhiza 20: 117-126.

Orlowska, E.; Przybylowicz, W.; Orlowski, D.; Turnau, K.; Mesjasz- Przybylowicz, J. 2011. The effect of mycorrhiza on the growth and elemental composition of Ni-hyperaccumulating plant Berkheya coddii Roessler. Environmental Pollution 159: 3730-3738.

Pasqualini, D.; Uhlmann, A.; Sturner, S.L. 2007. Arbuscular mycorrhizal fungal communities influence growth and phosphorus concentration of woody plants species from the Atlantic rain forest in South Brazil. Forest Ecology and Management 245: 148-155.
Perner, H.; Schwarz, D.; Bruns, C.; Mader, P.; George, E. 2007. Effect of arbuscular mycorrhizal colonization and two levels of compost supply on nutrient uptake and flowering of pelargonium plants. Mycorrhiza 17: 469-474.

Rengel, Z. 2001. Genotypic differences in micronutrient use efficiency in crops. Communications in Soil Science and Plant Analysis 32: 1163-1186.

Sheng, M.; Tang, M.; Chen, H.; Yang, B.; Zhang, F.; Huang, Y. 2009. Influence of arbuscular mycorrhizae on the root system of maize plants under salt stress. Canadian Journal of Microbiology 55: 879-886.

Shokri, S.; Maadi, B. 2009. Effects of arbuscular mycorrhizal fungus on the mineral nutrition and yield of Trifolium alexandrium plants under salinity stress. Journal of Agronomy 8: $79-83$

Smith, S.E.; Jakobsen, I.; Gronlund, M.; Smith, F.A. 2011. Roles of arbuscular mycorrhizas in plant phosphorus nutrition: Interactions between pathways of phosphorus uptake in arbuscular mycorrhiza roots have important implications for understanding and manipulating plant phosphorus acquisition. Plant Physiology 156: 1050-1057.

Soil Taxonomy 1975. A Basic System of Soil Classification for Making and Interpreting Soil Surveys. U.S. Department of Agriculture's Soil Survey Staff, Washington, DC, USA.

Sudova, R. 2009. Different growth response of five co-existing stoloniferous plant species to inoculation with native arbuscular mycorrhizal fungi. Plant Ecology 204: 135-143.

Wu, Q.S.; Zou, Y.N. 2010. Beneficial roles of arbuscular mycorrhizas in citrus seedlings at temperature stress. Scientia Horticulturae 125: 289-293.

Wu, Q.S.; Zou, Y.N.; Liu, C.Y.; Lu, T. 2012. Interacted effect of arbuscular mycorrhizal fungi and polyamines on root system architecture of Citrus seedlings. Journal of Integrative Agriculture 11: 1675-1681.

Wu, Q.S.; Zou, Y.N.; Huang, Y.M. 2013. The arbuscular mycorrhizal fungus Diversispora spurca ameliorates effects of waterlogging on growth, root system, architecture and antioxidant enzyme activities of Citrus seedlings. Fungal Ecology 6: 37-43. 